\title{
Recognizing Human DNA versus Non Human DNA
}

\author{
Mimoza Canga ${ }^{1}$, Vito Antonio Malagnino ${ }^{2}$ \\ ${ }^{1}$ University of Medicine Tirana, 9400 Albania \\ ${ }^{2}$ Sapienza University of Rome, 00185 Italy
}

\begin{abstract}
Aim: To recognize the human DNA versus non human DNA. Material and methods. GeneMapper softwer uses parts of Allelic ladder and LIZ500 acurately identifies alelles of genotypes and size for each locus of each sample. Allelic ladder parts are divided into 4 special colored pannels. Each pannel had parts of alelles for each locus. Parts of allelic ladder present all possible alelles that humans contain for a particular lucus, where one individual has only one allel or two alelles for a certain locus. Results: Results taken for other samples where the gene hTERT was discovered, we found that this genetic marker is very stable even in cases where DNA was seriously dammaged. This result is supported by the fact that this marker is discovered in other samples. So the low percentages of gained DNA is directly related to DNA dammage and type of substrate used for depositing. The genetic markers have shown consistently higher stability against degradation .
\end{abstract}

Keywords: DNA, genetic markers, AmpFISTR Identifiler, vaginal epithelial cells, sperm cells

\section{Introduction}

The marker hTERT is determinant for the recognition of human DNA and DNS from different microorganisms. Genetic markers, which show polimorphism between the tissue and are used for the identity test, are found and determined in the non coding zones, in the zones between the genes and and inside the genes.[2]-[6]. The use of STR as genetic marker has been the best method used in determing the sample origine in other studies too [2],[11].The forensics labs often work on samples whose DNA is ruined [2]-[6],[26]. In the absence of undammaged DNA the PCR is not succesful, the higher the degrading level, the lower the posibilities for the successful replication of the DNA. The experiements done have shown that there is a mutual relationship between dhe size of the locus and the successful replication of the PCR from the dammaged samples [4]-[5],[9]. In the case of organic extraction from the blood samples there is enough DNA sample isolated for a replication analyses with PCR and in some cases it has failed because of the hem inhibitor [8]. Based on the these problems, it came up the idea of sample analyzing with biologic material by using two different extraction methods, organic extraction with chloroform phenol and extraction with Chelex-100 to compare the extracted DNA.

\section{AIM}

To recognize the human DNA versus non human DNA.

\section{Material and Methods}

The softwear GeneMapper uses the parts of so called Allelic ladder and those of LIZ500 acurately identifies the alelles of genotypes and their size for each locus of each sample. The parts of the alleic ladder are divided in four special colored pannels. In each pannel there are parts of alelles for each locus. The parts of Allelic ladder represent all the possible alelles the all humans contain in the world for a particular lucus, where exactly one individual has only one allel or two alelles for a certain locus. The parts of Size Standard presented in the last pannel with orange colour are the same for the Allelic ladder and also for samples that have a role in the determination of the size of the parts of sample alelles. After these steps, each sample is read for the final result and the determination of its profile[1],[20]-[26].The frequency of alleles and genotypes is determined only for the referred samples with full DNA profile. The identification of the genotype frequency in relation with the determined alleles is done by supposing the examined population in genetic balance of Hardy - Weinberg [2]-[6], [10]. The frequency of alleles and genotypes is determined only for the referred samples with full DNA profile. It is determined the frequency of gained alleles according to the formula: allele frequency=number of alleles gained/total number of samples analyzed [5], [6]. The identification of the genotype frequency in relation with the determined alleles is done by supposing the examined population in genetic balance of Hardy -Weinberg [3], [10].The other part of the biological material is taken from types as blood samples collected on the different objects as glass and soil, the epithelial vaginal and semmen that were separated in one tampon and mixed in another tampon, saliva samples from surfaces like envelopes, textile materials etc.

A main feature of the sample environment was the presence of humidity which favoured the growth and development of different microorganisms that have enzymes that dammage the DNA in our samples.

\section{Results}




\section{International Journal of Science and Research (IJSR) \\ ISSN (Online): 2319-7064}

Index Copernicus Value (2013): 6.14 | Impact Factor (2015): 6.391

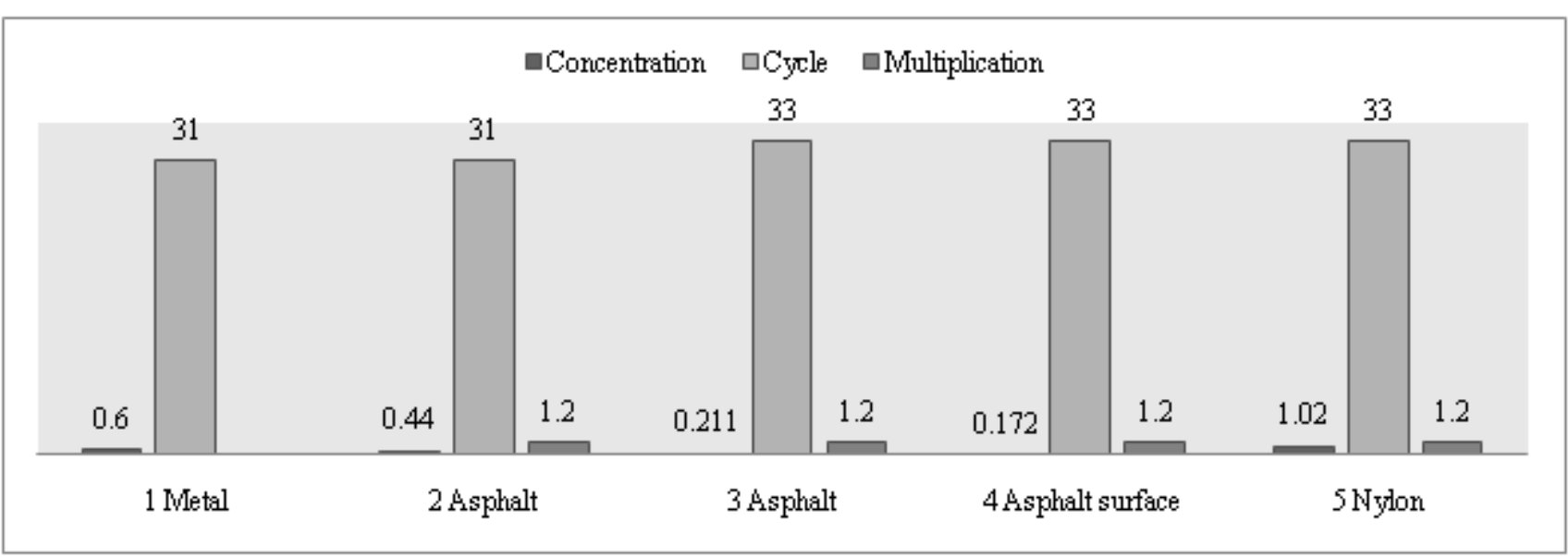

Graphic 1. There are data for the capilary electrophoreses and the time for the injection of the sample expressed in seconds normal time is 5 seconds, the gained profile or not of the DNA balancing or not of the parts of each alelle and data on dammaged locuses which are nor revealed during the analyses.

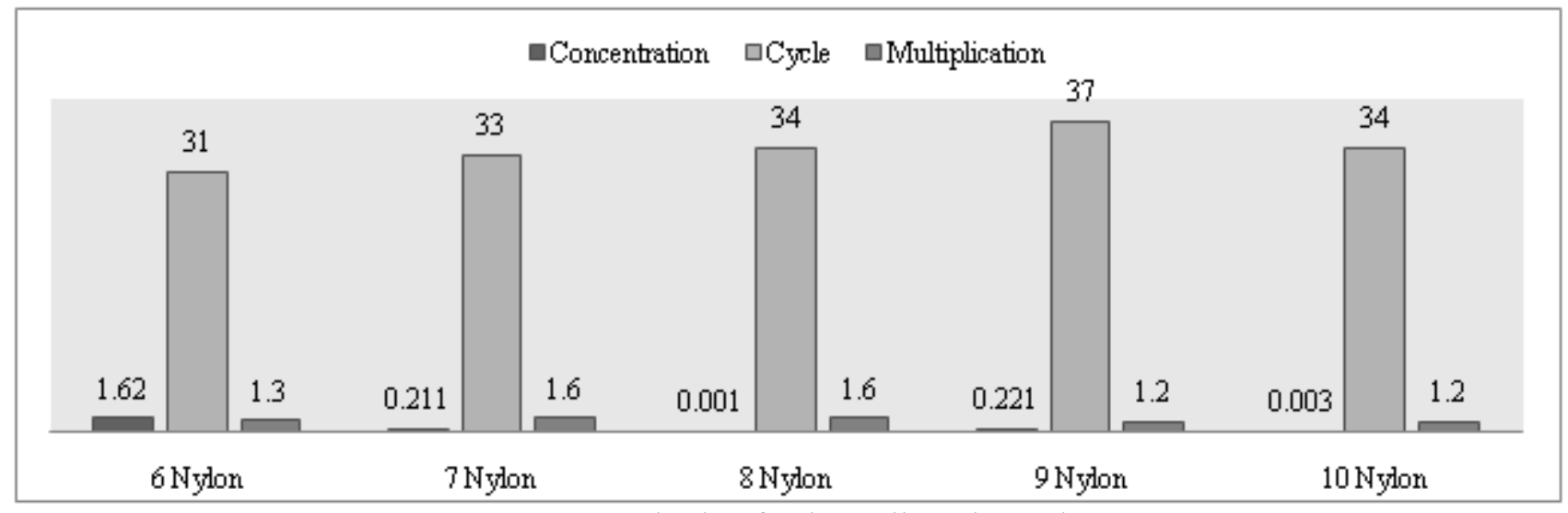

Graphic 2: The data for the capilary electrophoreses

From the results taken for other samples where the gene hTERT was discovered, it is noted that this genetic marker is very stable even in cases where DNA was greatly dammaged. This result is supported on the fact that this marker is discovered in other samples whereas other markers have failed to be discovered the set AmpFISTR Identifiler so the samples 8,9 and 10 . Referring to our results, we think that the low percentages of gained DNA in samples 8,9 and
10 are directly related to DNA dammage and the type of substrate used for depositing. We should mention that despite this fact, the genetic marker hTERT has been very stable regrardless to the dammage.With the spectrophotometric method we have determined and evaluated the total quantity of DNA in the analyzed material by including the free nucleotides, inhibitors and non human DNA.

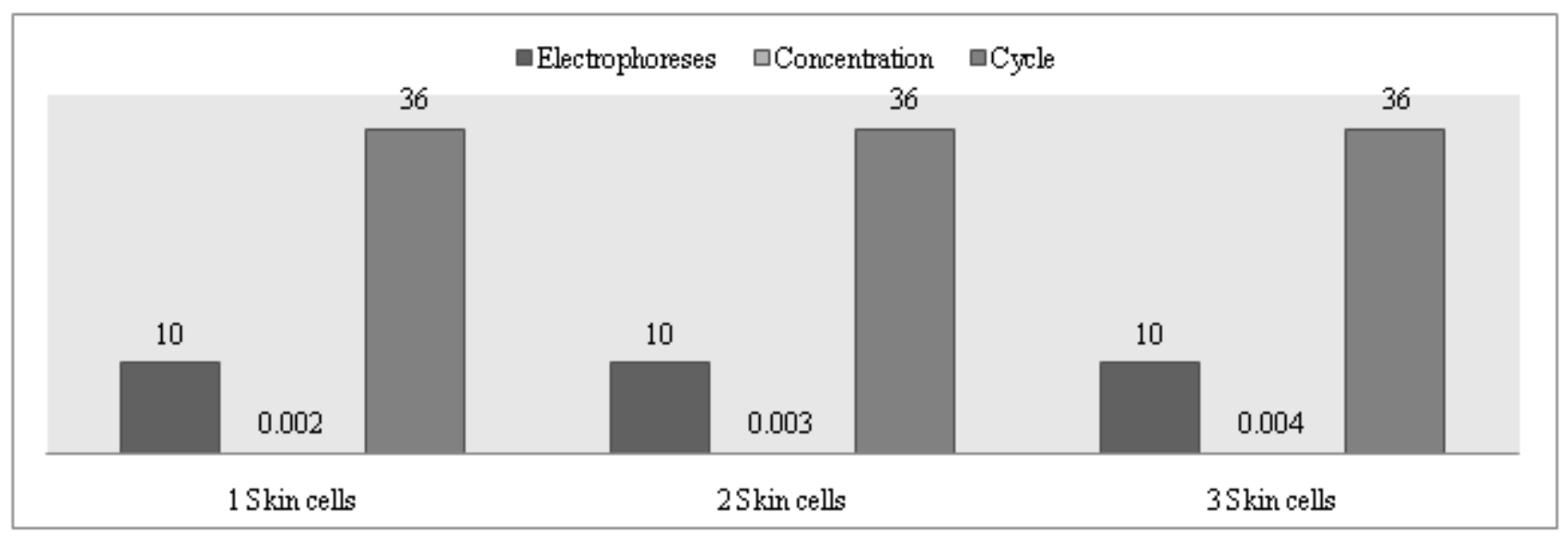

Graphic 3: For these samples the time of injection during the analyze in the capilar electrophoreses is also increased. 
International Journal of Science and Research (IJSR)

ISSN (Online): 2319-7064

Index Copernicus Value (2013): 6.14 | Impact Factor (2015): 6.391

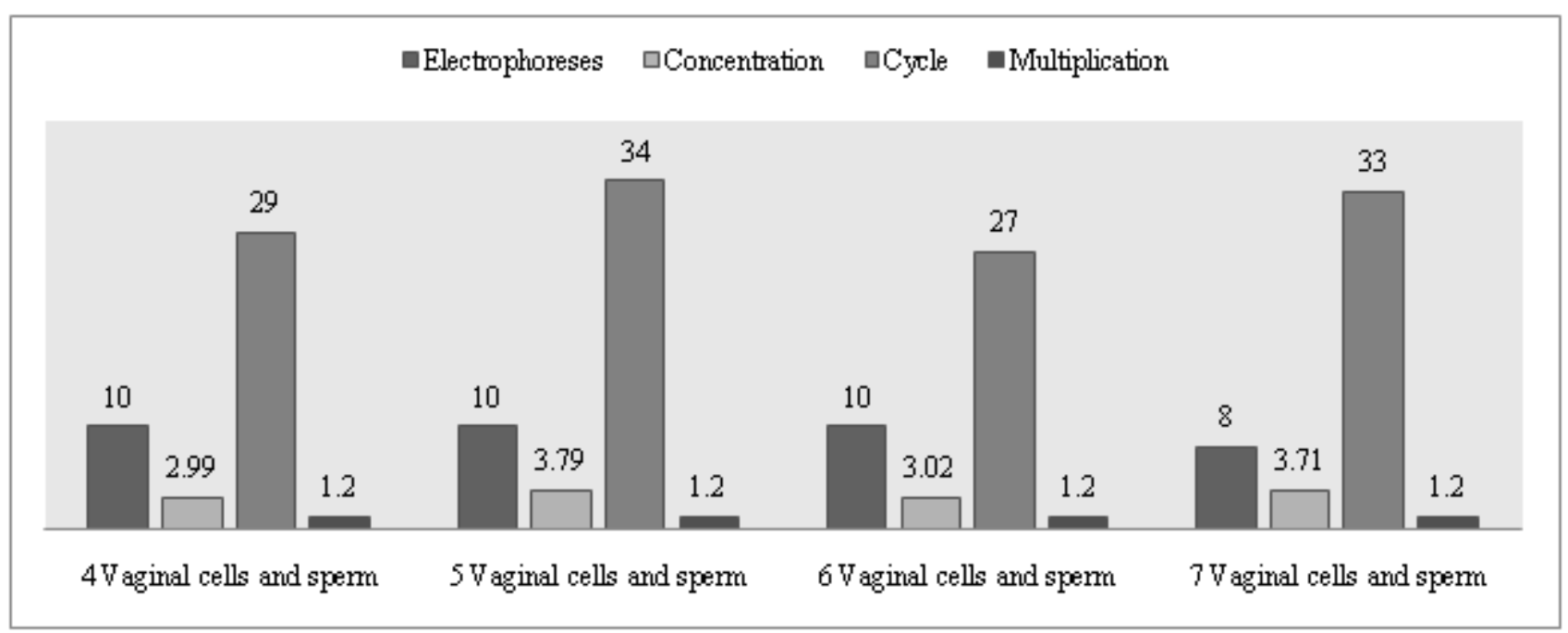

Graphic 4. Samples 4, 5, 6 and 7 were composed of two types of biological material: vaginal epithelial cells and sperm cells. These types of samples are typical in cases of rape. During differential extraction these mixed samples of biological material of two individuals are separated from each other to be analyzed as a separate sample. F1 fraction represents isolated DNA from epithelial cells of the vagina while the F2 fraction isolated DNA from sperm. As shown in the table the amount of DNA of the fraction F2 is several times less than that of fraction F1. This argues the fact that vaginal secretions and microorganisms that are found as normal flora of the vagina destroy the sperm by reducing its numbers over time.

\section{Disscussion}

For these samples the time of injection during analyzing done in capilary electrophoreses is also increased [14].The samples with large amount of DNA are diluted in the close amount of $1.2 \mathrm{ng} / 10^{\wedge} \mathrm{L}$. The blood samples in table 1 and 2 are collected from various substracts exposed to different conditions.

Negative results for the DNA extraction had samples 8,9 and 10. In these samples was discovered the gene hTERT, but as a result of the dammage of the blood deposit material, the markers of Identifiler Kit is not discover. The spongy nature of the substract has affected the small amount of isolated DNA. The effect of dammage for these samples is verified with the fact that eventhough the increase of DNA percentage by centrifuge and increse of the injection time still we could not have DNA profile. Based on the results of table 3 and table 4 we can say that the most problematic samples were the ones suspected of the presence of epithelial skin cells during touch of substract rubbing, the same with mouth cell epithelium. As a result of the low amount of DNA the samples are centrufuged to increase the percentage of DNA and in the discovery of DNA in the genetic analyzer has increased the injection time of sample form 5 seconds to 10 seconds maximal time. For this reason in these samples the alelle parts were not balanced. Samples 4, 5, 6 and 7 were composed of two types of biological material: vaginal epithelial cells and sperm cells. These types of samples are typical in cases of rape. During differential extraction these mixed samples of biological material of two individuals are separated from each other to be analyzed as a separate sample. F1 fraction represents isolated DNA from epithelial cells of the vagina while the F2 fraction isolated DNA from sperm. As shown in the table the amount of DNA of the fraction F2 is several times less than that of fraction F1. This argues the fact that vaginal secretions and microorganisms that are found as normal flora of the vagina destroy the sperm by reducing their numbers over time. The longer the time of sampling, the the lower are the opportunities to isolate cells of healthy sperm[7],[2]-[6].[9], have analyzed the stability of the short repeated framents of the same locus by using the humidity as a dammaging factor of the blood and saliva samples. From the results, it is seen that STR segments show a high stability to the dammage mainly during the first week, where is gained the full profile of DNA, later the longer the time of izolation the more failure to show the profile. Based on the results obtained through VIC detectorwe can say that the threshold cycles for samples extracted with organic extraction technique is higher than that of samples where the extraction is performed with Chelex. It may be noted that time spent during the isolation of DNA with Chelex method is two times shorter than that of organic extraction [8],[12],[13],[27][30].In their studies, in most of the samples used the most efficient method was the Chelex one.In the following tables are presented all the possible existing alleles of each locus where every human individual possesses only one or both alleles. Our results are consistent with the results obtained from the study of Kubat et., al in the all the locus[19]. The comparison of the results obtained from Jakovski $Z$ et al., 2006 do not show a significant change in alelles with high frequency other than in locus TH01 and D18S51[15].

\section{Conclusions}

The samples have been in different levels of damage of DNA molecules, this marker has shown high stability to environmental factors. The genetic markers have shown consistently higher stability against degradation under environmental conditions. We suggest using the AmpFISTR Identifiler kit in case of DNA analysis for the purpose of determining the DNA profile. 


\section{International Journal of Science and Research (IJSR) \\ ISSN (Online): 2319-7064}

Index Copernicus Value (2013): 6.14 | Impact Factor (2015): 6.391

\section{Acknowledgment}

To perform and report this study was received no financial support from any companies or from a national or international funding source.

\section{References}

[1] Anderson, H., Nilsson, M., Budowle, B., Lundberg, H., \& Allen M. 2006: Nuclear and mitochondrial DNA quantification of various materials. Forensic Science International 164, pp. 56.64 .

[2] A.Linacre , L. Gusmão, W. Hecht, A.P. Hellmann, W.R. Mayr, W. Parson, M. Prinz, P.M. Schneider, N. Morling. ISFG: Recommendations regarding the use of non-human (animal) DNA in forensic genetic investigations. Forensic Science International: Genetics. Volume 5, Issue 5, November 2011, Pages 501-505

[3] Buttler, M. J. 2011: Forensic DNA Typing: Methodology. Elsevier Publishers, USA.

[4] Buttler, M. J. 2010: Foundamentals of Forensic DNA Typing (3th ed). Elsevier Publishers, USA.

[5] Buttler, M. J. 2005: Forensic DNA Typing (2nd ed). Elsevier Publishers, USA.

[6] Buttler, M.J. 2007: Short tandem repeat typing technologies used in human identity testing. BiTechniques 43: Su $\sim \mathrm{Sv}$, doi 10.2144/000112582.

[7] Buttler, M. J. 2006: Genetics and Genomics of Core Short Tandem Repeat Loci Used in Human Identity Testing. J. Forensic Sci, Vol. 51. No. 2, pp. 253.265.

[8] Buckleton, J., Triggs, M. Ch., \& Walsh, J. S. 2005: Forensic DNA Evidence Interpretation, CRC Press, USA.

[9] Davoren, J., Vanek, D., Konjhodzic, R., Crews, J., Huffine, E., and Parsons, J. Th. 2007: Highly Effective DNA Extraction Method for Nuclear Short Tandem Repeat Testing of Skeletal Remains from Mass Graves. Croat Med J. August, 48(4): pp. 478485.

[10]Dixon, L. A., Dobbins, A. E., Pulker, H. K., Butler, J.et al. 2006: Analysis of artificially degraded DNA using STRs and SNPs - results of a collaborative European (EDNAP) exercise. Forensic Science International, 164, pp. 33-44.

[11]Fung, W. K., \&HuY, Q. 2008: Statistical DNA Forensics. UK. John Wiley \& Sons Publishers. UK.

[12]Goodwin, W., Linacre, A., \&Hadi, S. 2011: An Introduction to Forensic Genetics, John Wiley \& Sons Publishers. UK.

[13]Hoff-Olsen, P., Mevag, B., Staalstrom, E., Hovde, B., Egeland, Th., Olaisen, B. 1999: Extraction of DNA from decomposed human tissue, an evaluation of five extraction methods for short tandem repeat typing. Forensic Science International, 105, pp. 171183.

[14] Hudlow, W. R., Chong, M. D., Swango, K. L., Timken, M. D., \&Buoncristiani, I. 2008: A quadruplex real-time qPCR assay for the simultaneous assessment of total human DNA, human male DNA, DNA degradation and the presence of PCR inhibitors in forensic samples: A diagnostic tool for STR typing. Forensic Science International: Genetics, volume 2, Issue 2, pp. 108-125.

[15]Jacquie, T. K., \& Lyndsey, B. 2008: Essentials of Nucleic Acid Analysis. LGC, Teddington, Middlesex,
RSC Publishing. UK.

[16] Jakovski, Z.,Nikolova, K.,Furac, I.,Masic, M.,Janeska, B.,Kubat, M.2006: Allele Frequencies for 15 STR loci in a population from the Republic of Macedonia.IntJLegal Med. Jan; 120 (1): 53 - 5. Epub 2005 Aug 9.

[17]Jeran, N., Hava, D., Ivanovi, V., Rudan, P. 2007: Genetic Diversity of 15 STR Loci in A Population of Montenegro. Coll. Antropol. 31, 3, pp. 847-852.

[18]Keckarevic, D., and Pavicevic, D. S. 2009: University Belgrad, Faculty of Biology: Serbian Population Data. Personal communication.1Kiely, F. T. 2006: Forensic Evidence: Science and the Criminal Law (2th ed). CRC Press. USA

[19]Kobilinsky, L., Levine, L., \& Margolis-Nunno, H. 2007: Forensic DNA Analysis, chapter 4. Chelsea House Publishers. USA.

[20]Kubat, M., Skavic, J., Behluli, I., Nuraj, B., Bekteshi, T., Behluli, M., Klaric, I. M., Pericic, M. 2004: Population genetics of the 15 AmpFISTRI dentifiler loci in Kosovo Albanians. Int J Legal Med. Apr; 118(2) : 115-8. Eub 2004 Jan 23.

[21]President's DNA Initiative. 2006: DNA Analyst Training-Laboratory Training Manual User Guide, Protocols. Bloodstain Indication: Kastle-Meyer Test; Section 2.15, pp. 1-2.

[22] President's DNA Initiative.2006: DNA Analyst Training. Laboratory Training Manual User Guide, Protocols. Chelex ${ }^{\circledR} 100$ Non Differential Extraction; Section 35pp. 1.5.

[23] President's DNAInitiative.2006: DNA Analyst Training. Laboratory Training Manual User Guide, Protocols. Chelex®100 Differential Extraction; Section 3.06, pp.1.5.

[24] President's DNAInitiative.2006:

[25] DNA Analyst Training. Laboratory Training

[26] Manual User Guide, Protocols. Quantifier Quantization Procedure; Section 3.11, pp. 1.14.

[27] President's DNAInitiative.2006: DNA Analyst Training. Laboratory Training Manual User Guide, Protocols. PCR Amplification and Electrophoresis of STRs; Section 4.01, 5.02, 6.01.

[28] President's DNA Initiative. 2006: DNA Analyst Training. Laboratory Training Manual User Guide, Protocols. PCR Interpretation; Section 6.02, pp. 1.7.

[29] Semikhodskii, A. 2007: Dealing with DNA Evidence, chapters 1, 2, 3. Taylor \& Francis e.Library. Publishers, USA.

[30] Thompson, J., Kibler, J., and Kupferschmid, Th. 2009: Comparing Five ForensicDNA Extraction Methods. Sorenson Forensics, Salt Lake City, UT 84115, Poster presentation. USA.

[31] Timken, M., Swango, K., Orrego, C., and Buoncristiani, M. 2005: A Duplex Real. Time qPCR Assay for the Quantification of Human Nuclear and Mitochondrial DNA in Forensic Samples: Implications for Quantifying DNA in Degraded Samples. J Forensic Sci, Sept. Vol. 50, No. 5. Paper ID JFS2004423.

[32] Vallone, P. M., Hill, C. R., \& Butler, J. M. 2008: Demonstration of rapid multiplex PCR amplification involving 16 genetic loci. Forensic Science International, pp. 42. 45.

[33] Viltrop, T., Krjutskov, K., Palta, P., Metspalu, A. 2010: 


\section{International Journal of Science and Research (IJSR) \\ ISSN (Online): 2319-7064 \\ Index Copernicus Value (2013): 6.14 | Impact Factor (2015): 6.391}

Comparison of DNA extraction methods for multiplex polymerase chain reaction. Analytical Biochemistry 398 (2010) pp. 260-262.

\section{Author Profile}

Dr. Mimoza Canga is laureate at the University Sapienza, Roma- Italy and has a $\mathrm{PhD}$ from the University of Tirana. Currently works in the University of Vlore, Department of Public Health, Vlore-Albania

Professor Vito Antonio Malagnino is laureate in the Faculty of the Medicine with excellent grades. He is specialized in odontostomatology in the University of Roma- Sapienza Italy. He is the chief of the endodontic in Sapienza- University.

Volume 5 Issue 7, July 2016 www.ijsr.net 